\title{
Interpretation of Sense/Meaning in the Communicative Field
}

\author{
Emilia A. Tajsin', Alexei S. Gurianov² \\ Kazan State Power Engineering University. Kazan, Russia

\section{Abstract}

The past century has shown the conversion of a so-called anthropological turn which began with works of Franz Brentano, into a linguistic turn (Richard Rorty's term). The philosophy of language took the place of what once had been classical theory of cognition. It has become either a kind of epistemology, or analytical philosophy, or even a general theory of knowledge called in Greece, Germany and Russia gnoseology (from Greek: gnosis - knowledge).

It is necessary to make some clarifications in understanding the current intellectual situation in the field of communication theory.

Communication is a term containing a root morpheme 'uni' with the meaning of "one", "unity". For our purposes, the English word "conversation" is more suitable because, denoting a talk, it actually has the primary existential meaning of "living together". Developing this topic, we can rely on the classic research in the field of theory and practice of communication conducted over several decades by the American specialist in the field of social psychology Deborah Tannen.

\section{Keywords}

Communication; Understanding; Background ("Tacit") and Focal Knowledge; Metamessage;

Double Helix of Communication 


\section{Интерпретация смысла в коммуникативном поле}

\section{Тайсина Эмилия Анваровна ${ }^{1}$, Гурьянов Алексей Сергеевич ${ }^{2}$}

Казанский государственный энергетический университет. Казань, Россия

\section{Аннотация}

Прошлый век продемонстрировал превращение долгого антропологического поворота в лингвистический поворот. В результате философия языка заняла место классической гносеологии. Она стала либо своеобразной эпистемологией, либо даже общей теорией познания.

Необходимо внести некоторые разъяснения в понимание сложившейся интеллектуальной ситуации в области действия теории коммуникации.

Коммуникация - термин, содержащий корневую морфему со значением «один», «единство». Для наших целей больше подходит английское слово "conversation", потому что, обозначая беседу, он в действительности обладает первичным бытийным смыслом «совместно жить». Развивая данную тему, мы можем опереться на ставшие классическими исследования в области теории и практики коммуникации, проводимые в течение нескольких десятилетий американским специалистом в сфере социальной психологии Деборой Таннен, $\mathrm{PhD}$.

\section{Ключевые слова}

коммуникация; понимание; фоновое и фокусное знание; метамесседж; двойная спираль коммуникации

Это произведение доступно по лицензии Creative Commons «Attribution» («Атрибуция») 4.0 Всемирная

1 Email: Emily_Tajsin[at]inbox.ru

2 Email: alexeigurianov[at]rambler.ru 
The twentieth century has demonstrated the transformation of a long anthropological (basically Kantian) turn into a linguistic turn, renowned especially after the works of Wittgenstein. As a result, the philosophy of language took the place of classical gnoseology playing either a role of some kind of epistemology or even pretending to become a general theory of knowledge. Suffice it to say that in the Oxford Handbook of Contemporary Philosophy (Oxford University Press, 2013), the Chapter "Truth" (by Horwich, Paul) doesn't belong to the section "Epistemology", but to "Philosophy of language". (Jackson \& Smith, 2013)

We think it is necessary to make some clarification and explanation in the understanding of the current intellectual situation in the aspect of communication theory. It cannot be ruled out that the next stage will be, relatively speaking, an "ethical turn." This can be traced, for example, in the rapid evolution of the philosophy of J. Habermas and that of late U. Eco.

Communication is a term containing a root morpheme with the meaning of "unitedness [togetherness], unity". For our purposes, the English word "conversation" (from the Latin conversare) is more suitable, because, denoting a talk, a dialogue or a multilogue, a parley, it actually has the primary ontological meaning of "living together". (Webster's Seventh New Collegiate Dictionary, 1963). Not just chatting, and not even talking in the first place, but -- co-existing; Experiencing something together and simultaneously.

Developing this topic, we take advantage in making use of the classic research in the field of theory and practice of communication conducted for several decades by the American psychologist Deborah Tannen, PhD.

The key word of these studies is the term introduced by D. Tannen herself to designate a certain personal dimension of the sociocultural context of the information transmitted by the communicator: metamessage, meta-notification.

In the texts of neo-Kantian postmodernism, there are other terms to denote practically the same: "personal knowledge", "tacit knowledge", "background", "prerequisite" knowledge; context... "cryptocomponent of meaning"... etc. However, the point is not so much in the terms themselves, as in the variants of sense carried by the linguistic units mentioned.

The idea of existence of semantic shifts in the process of communication seems truly trivial. However, there would have been no need for any theory, if understanding were problem-free and absolute. The difference between such profane view of understanding and D. Tannen's approach lies in her clear awareness of the real denotatum standing behind the concept of metamessage; namely: it is the subjective mutual relations of communicators that are developed for one reason or another. These relationships are not specifically announced in the process of a conversation, they are not explicitly verbalized, but metamessage is a text, and, moreover, one to which authors and recipients react most strongly and to which they listen with caution, and with deep personal interest. (Tannen, 1987, p. 16). 
This attentiveness, this interest, which often develops into alertness, is explained, and convincingly, by the emotional involvement of the interlocutors in the company, in living together.

Many of us underestimate the texts that do not contain important information. Then we should seriously revise our assessments of, say, Hemingway's texts; how do his dialogues differ from the plain everyday telephone chats? In no way. But one cannot ignore the cumulative meaning of the communication field, the non-spatial terrain where the conversation lives. It cannot be conveyed without words; background knowledge cannot exist without the "ground", focal knowledge. However, "just" message, the text "in itself", carrying some information, does have a context: it conveys not only conceptual content expressed in logical forms of cognition, i.e., concepts and judgments, but also much more. In this way we establish, maintain, adjust our relations, and manage this area of life. In the texts exchanged by communicators, not only the cognitive side is important, namely, conceptual information itself, but also a motley fan of modalities. Communication does not lie in the field of dictionary definitions; the way we speak - how loudly and quickly, with what intonation and stress - is a metamessage, a meta-notice, and it carries social sense/ meaning. We test, we tease and flirt, we explain, and stalk, and wonder; we behave friendly, we are hostile, or mysterious; we convey our desire to approach or recoil.

Meta-notification is a field of non-verbal communication, the content of which is the main social contradiction that always exists in a personal form: the desire to be independent and the equal desire to be involved in a group. (Tannen, 1987, pp. 16-17). The desire to be connected with others and the desire to be left alone in solitude are universal and fundamental motives for communication. Anything we say for the sake of showing closeness and involvement naturally poses a threat to our own and others' identities. Anything we say to show a desire to distance ourselves is a natural threat to our need to be in a society.

Sometimes, to illustrate this contradiction, the example of A. Schopenhauer is cited: this is the coexistence of a group or family of porcupines in winter conditions. For the sake of warmth, they try to huddle together, but the sharp needles work, and the porcupines move away... The winter cold forces them again to seek closeness, but the natural prickling structure compels them to keep their distance. Trying to respect the conflicting aspirations of closeness and distance binds them us - in a double chain. It is double, because any action in support of any of these basic aspirations necessarily interferes with the second, unsupported aspiration. It is double, because this existence-in-communication is the source of both comfort and pain. Because of the existence of this chain, communication can never be perfect; we cannot stop and fall into stasis, just as we cannot break out of the circle, leaving the field of "living together", "conversation", communication. An attempt to set aside communication, leaving it, will only lead to the fact that the social force will soon throw the new-born hermit back into the maelstrom of involvement. 
D. Tannen says that the porcupine metaphor actually misleads us in a way. It presupposes a sequence of actions: closer - further, pull up - push off; in fact, our aspirations for independence and inclusion, isolation and connection exist and manifest simultaneously, indissolubly. (Tannen, 1987, p. 20). This statement seems trivial; however, erroneously. The fact is that the contradiction under discussion is not a conflict, although this is how the theory refers to the highest degree of sharpening of the contradiction. In a state of a conflict, a person feels herself flouncing about or already torn between two alternatives. This is not a state of ambivalence, either; - this latter one appears in a sense of doubt about two paths to one goal, in the absence of a holistic assessment of the same situation. It is precisely a twisted double helix, no less strong than DNA, and equally fundamental. At the same time, we can say that the discussed social contradiction constitutes the basis of the behavior of not only individuals-people, but also of certain individual cultures. Intercultural communication is subject to the same force that regulates coexistence, and different cultures can put different accents and manifest different forms of expressing their values.

Freedom and security, familiar and foreign, "strange", in this vein, and most likely in general, are opposite values. The priority of the theme of freedom in Western European or American consciousness and, conversely, the theme of involvement (family, clan, etc.) in the world outside the "West" is widely known. (Tannen, 1987, p. 18). This, however, is the topic of another study. In any case, a person has to, in the process of folding and functioning of a common life, in any community, maintain a balance of basic opposites through all kinds of social and personal adaptations, abstractions of approximation, which in ethics and etiquette is called politeness.

It is not far from here to the ethical turn.

\section{References / Список литературы}

Jackson, F., \& Smith, M. (Eds.). (2013). The Oxford Handbook of Contemporary Philosophy. Part IV. Philosophy of Language. Oxford University Press.

Tannen, D. (1987). That's Not What I Meant! How conversational style makes or breaks relationships. New York: Ballantine Books Edition.

Webster's Seventh New Collegiate Dictionary. (1963). Springfield, Mass. 